\title{
ケアチームによる排便コントロールへの共同介入の評価
}

\author{
渡辺智康 ${ }^{* 1}$, 山崎 恵 $^{1}$, 高取孝一 ${ }^{1}$, 山本園栄 ${ }^{2}$, 安藤哲信 ${ }^{1}$, 早川 達 $^{3}$ \\ 吉備高原ルミエール病院薬斉科 ${ }^{1}$ \\ 吉備高原ルミエール病院看護部 2 \\ 北海道薬科大学薬学部薬学科臨床薬学系薬物治療学分野 3
}

\section{Evaluation of Joint Intervention by Care Team in Defecation Control}

\author{
Tomoyasu Watanabe ${ }^{* 1}$, Megumi Yamasaki ${ }^{1}$, Kouichi Takatori ${ }^{1}$, \\ Sonoe Yamamoto ${ }^{2}$, Tetsuaki Ando ${ }^{1}$ and Toru Hayakawa ${ }^{3}$ \\ Department of Hospital Pharmacy, Kibikougen Lumiere Hospital ${ }^{1}$ \\ Department of Hospital Nursing, Kibikougen Lumiere Hospital ${ }^{2}$ \\ Department of Pharmacotherapy, \\ Hokkaido Pharmaceutical University School of Pharmacy ${ }^{3}$ \\ Received September 14, 2006 \\ A ccepted January 9, 2007
}

We prepared a check list based on a standard care plan for constipated patients with the aim of achieving good defeca tion control and together with nurses and caregivers, used it in conducting medication management.

Our subjects were 146 inpatients taking laxatives at the Kibikougen Lumiere Hospital. In consideration of objectivity, we excluded 64 patients, leaving 82 patients for the evaluation. The period of our study was December 2004 to May 2005 and medication management was conducted in the last 3 months. The frequency of constipation and drug costs were compared between before and after medication management was introduced.

The average frequency of constipation $(2.2 \pm 0.3$ times vs. $1.6 \pm 0.2$ times; $p<0.05)$ and the average drug costs $(1,692+$ 247.1 yen vs. $1,320 \pm 212.2$ yen; $p<0.05)$ decreased significantly after the introduction of medication management. We therefore consider that our joint intervention with nurses based on use of the check list was successful in improving defeca tion.

Key words - constipation, standard care plan, check list, evaluation, care team

緒言

標準ケア計画を利用した薬学的管理は，薬斉管理指導 業務の効率化や質の確保において重要である1).また， 標準ケア計画の重要な事項をまとめたチェックリストを 作成することで，さらなる薬剂管理指導業務の効率化お よび標準化が可能である．実際にさまざまな疾患で標準 ケア計画を利用した薬学的管理が実施され成果を挙げて (る ${ }^{2-5)}$. 一方, 最近の薬剂師業務は薬剂管理指導業務 に加えて，裖瘡や NST(Nutrition support team)などのチー 厶医療の一員としての活動も重要になってきている . 吉備高原ルミエール病院(以下, 当院と略す)は医療型
療養病床160床，介護型療養病床60床の高齢者を主体と した病院である.高齢者において最も一般的な疾患は 「便秘症」であり，当院においても多くの患者に対し排 便コントロールの目的で緩下剂が投与されている. 弚こ で，われわれは良好な排便コントロールを実施すること を目的として，「便秘症」の標準ヶア計画に基づきチェッ クリストを作成し，薬学的管理を実施した。また，「便 秘症」は看護においても食事と並び重要な問題であるた め, 薬剂科と看護部か協力し, チームとして排便コント ロールを試み, 問題点の抽出を行った .

今回，「便秘症」に対して薬剤師と看護師のケアチー ムが共同介入することによる排便コントロールの臨床評 価および,作成したチェックリストの有用性を検討した . 


\section{方法}

1. 看護部との協力体制とチェックリストの作成 排便コントロールを看護部と共同で行うにあたり，各 病棟から看護師2名, 介護職2名および, 薬剤師1名で構 成される排便コントロール委員会を設置した . 排便コン トロール委員会は, 2力月間, 計8回開催し, 排便に関す る勉強会や記載表現(排便時間, 便性状, 排便量など)の 統一化作業を行った .

本研究を実施するにあたり，看護部では排便回数，便 の性状, 腹満の有無(腸の蠕動運動の状態), 直腸指診, 腹痛・出血の有無, 水分量, 食事量, 排泄スタイル(卜 イレ・ポータブルトイレ・オムツ)などのモニタリング を行うこととし, 看護部で使用するチェックリスト(看 護部用)を作成した .

薬剂科では「便秘症」の標準ヶア計画1に，合併症， 病歴向，患者情報 ${ }^{87}$, 問診6,7などの薬学的管理に関する 項目を追加し,重要な事項をまとめたチェックリスト(薬 剂科用)を作成した。

\section{2. 排便コントロールへの関与}

担当薬剂師は, 本チェックリストを使用し, 禁忌・慎 重投与薬剂, 合併症, 副作用の有無などのチェックと看 護師のモニタリング結果を考慮した上で, 投与薬阁の妥 当性・効果判定を行った. 薬冏師と看護師のケアチーム による共同介入の結果，問題点が抽出された患者に対し ては, 排便コントロール委員会で協議を行い, 医師へ使 用薬剂, 投与時間, 食事・水分などの变更を依頼した。

\section{3. 臨床評価}

2004年12月から2005年5月までの6力月間, 継続して 入院している患者で, 排便コントロールの目的て緩下剂 を投与されていた146名を研究対象とした。研究期間中 に死亡や退院した患者, 肺炎などの合併症により食事捸 取や内服が困難となった患者, 痴呆などにより排便の確 認が不明瞭であった患者を除く82名を評価対象とした .
患者は平均年齢82歳で，女性57名，男性25名であった． 患者の診断名の内訳は脳梗塞後遺症40名, 認知症 7 名, 脳出血後遺症6名, 糖尿病5名, 脊髄損傷4名, パーキン ソン症候群3名, 弚の他17名であった .なお, 本研究は 薬事委員会での承認を受け, 通常の薬剂管理指導業務の 一環として実施した．また，倫理面においては患者個々 のプライバシーの保護に十分配慮して研究を行った .

ケアチームによる共同介入をしないろ力月(介入前 : 以 下, 対照群と略す)と共同介入をした3力月(介入後 : 以 下, 介入群と略す)で, 便秘回数, 排便回数, 便性状, 薬斉の変更件数, 薬剂費, 使用薬剂量を比較検討した。

看護診断を参考にして3日間排便なしを便秘回数 1 回 とした .中等量以上の排便を排便回数1回とし, 少量の 排便は回数から除外した . 便性状は普通便, 硬便, 泥状 便，不消化便，水樣便に分類して分析した.表1に便秘 の定義を表 2 に便性状の分類を示す ${ }^{9}$.

得られた值は平均値士 標準誤差として示し，2群間の 平均値の比較には Student の $\mathrm{t}$ 検定を用いた . 得られた 危険率が5\%末満を有意水準とした。

\section{結果}

\section{1. チェックリスト}

作成した看護部用および薬剂科用チェックリストを关 れ帒れ図1，2に示す。

看護部用チェックリストは, ケアチームにおける共通 項目の叙述的な記載を省略できるようになり，患者の状 態把握も容易になった . また, 薬斉科用チェックリスト は処方内容, OTC 薬等の確認, 禁忌・慎重投与薬剂, 便秘症状を引き起こす疾患, 便秘の診断, 患者要因, 指 導項目, 投与薬剂の妥当性の検討, モニタ一項目, 副作 用の有無，プロブレムリスト，退院時指導などを項目ご とに分類して記載できるようになり, 問題点の抽出が確 実となった。

表 1 . 便秘の定義

便秘の定義

排便回数の減少や硬く乾燥した便を排泄している状態、またはその危険性が高い状態 以下の項目の 1 つ、またはそれ以上が存在する状態を便秘とする。

(1) 硬い、有形性の便

(2) 排便が週 3 回以下

（3）緩下剂、浣腸の常用

(4) 腹部膨満感

（5）排便時のいきみ、疼痛 
表 2 . 便性状の分類

\begin{tabular}{|l|l|}
\hline \multicolumn{1}{|c|}{ 便の種類 } & \multicolumn{1}{c|}{ 便の性状 } \\
\hline \hline 普通便 & 有形、非乾燥、硬くない状態の便 \\
\hline 硬便 & 硬く乾燥した便 \\
\hline 泥状便（軟便を含む） & 無形、泥のような状態の便 \\
\hline 不消化便 & 食物残渣がタられ酸性臭を放つような便 \\
\hline 水様便 & 無形であり下痢様の水分を含んだ便 \\
\hline
\end{tabular}

\begin{tabular}{|c|c|c|c|c|c|c|c|c|c|c|c|c|c|c|}
\hline & \multirow{3}{*}{ 食事 } & & \multicolumn{2}{|c|}{ 排泄スタイル } & \multicolumn{3}{|c|}{ 排便コントロール目的栔剂 } & \multicolumn{2}{|c|}{ 排便抑制焦都 } & \multicolumn{2}{|c|}{ 便秘の型 } & \multicolumn{2}{|c|}{ 主智患 } \\
\hline ID & & & & RイL & & & & & & & & & & \\
\hline 名前 & & & & ポータブル & & & & & & & & & & \\
\hline 年齢 & & 水分 & & オムッ & & & & & & & & & & \\
\hline 使用 & 菓郕 & 単位 & 1 & 2 & 3 & 4 & 5 & 6 & 7 & 8 & 9 & 10 & 11 & 12 \\
\hline 酸化マグニ & 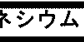 & $\mathrm{g}$ & & & & & & & & & & & & \\
\hline センナ & & $\mathrm{mL}$ & & & & & & & & & & & & \\
\hline ブルゼ二 & & 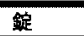 & & & & & & & & & & & & \\
\hline ラキりセ & Jン液 & 滴 & & & & & & & & & & & & \\
\hline テレミン & オフト坐 & 個 & & & & & & & & & & & & \\
\hline タリரேリ： & 浣腸 & 個 & & & & & & & & & & & & \\
\hline パトシ: & & 鏙 & & & & & & & & & & & & \\
\hline ガスモチ: & & 鋐 & & & & & & & & & & & & \\
\hline 天建中湯 & & $\mathrm{g}$ & & & & & & & & & & & & \\
\hline 天黄甘草 & 昜 & $\mathrm{g}$ & & & & & & & & & & & & \\
\hline 排便状況 & 深夜 (0 & $-8: 30)$ & & & & & & & & & & & & \\
\hline & 日勤 (8: & $17: 30)$ & & & & & & & & & & & & \\
\hline & 隻夜(17 & $-0: 00)$ & & & & & & & & & & & & \\
\hline 腸音 & & & & & & & & & & & & & & \\
\hline 面腸指祅 & & & & & & & & & & & & & & \\
\hline 血便 & & & & & & & & & & & & & & \\
\hline 副作用 & & & & & & & & & & & & & & \\
\hline その他 & & & & & & & & & & & & & & \\
\hline
\end{tabular}

図 1 . 便秘患者のチェックリスト(看護部用)

\section{2. 臨床評価}

患者一人当たりの便秘回数は対照群が平均 $2.2+0.3$ 回

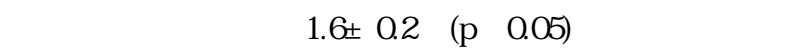
た(図3)．また，患者一人当たりの排便回数は対照群が

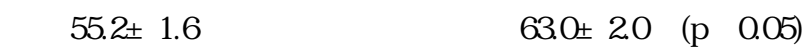
と有意に増加した(図4). 性状では泥状便が介入群で増 加していたが , 水樣便および不消化便の増加はなかった (図5).

さらに, 薬剂変更件数は対照群が41件に対して介入群 が52件と増加した．変更内訳は対照群の多くが薬斉の増 量による変更であったが, 介入群では薬剂の減量による 変更が増加した(表3).一方，患者一人当たりの薬刘費

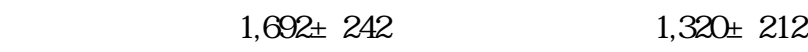
円 $(p<0.05)$ となり，介入群で有意な゙減少か認められた(図 6) . 使用薬剂量の変化では特に浣腸において介入群の使 用本数が対照群の $42 \%$ と大幅な減少となったが, ピコス ルファート Na, 酸化マグネシウムでは対照群に対して 介入群で使用量が増加した(表4).

\section{考察}

薬剂師は看護部用チェックリストから患者の正確な排 便状況を把握し，薬剂科用チェックリストを使用して問 題点を抽出した上で, 看護師とのケアチームにより排便 コントロールに共同介入した . 炎の結果, 患者一人当た りの便秘回数は対照群と比較して介入群で有意に減少し た.また，患者一人当たりの排便回数は対照群と比較し て介入群で有意に増加した . 便性状では泥状便が介入群 で増加していたが，水樣便および不消化便の増加がな かった .これらの結果からケアチームによる排便コント ロールへの共同介入は「便秘症」の改善に有効であった と考える.

一方，患者一人当たりの薬剂費は対照群と比較して介 入群で有意な゙減少か認められ, 薬剂変更件数は介入群で 増加した . 変更内訳として対照群では増量件数が多かっ たが, 介入群では増量件数より減量件数が多くなった . 対照群では排泄があれば薬剂変更が行われない傾向にあ 


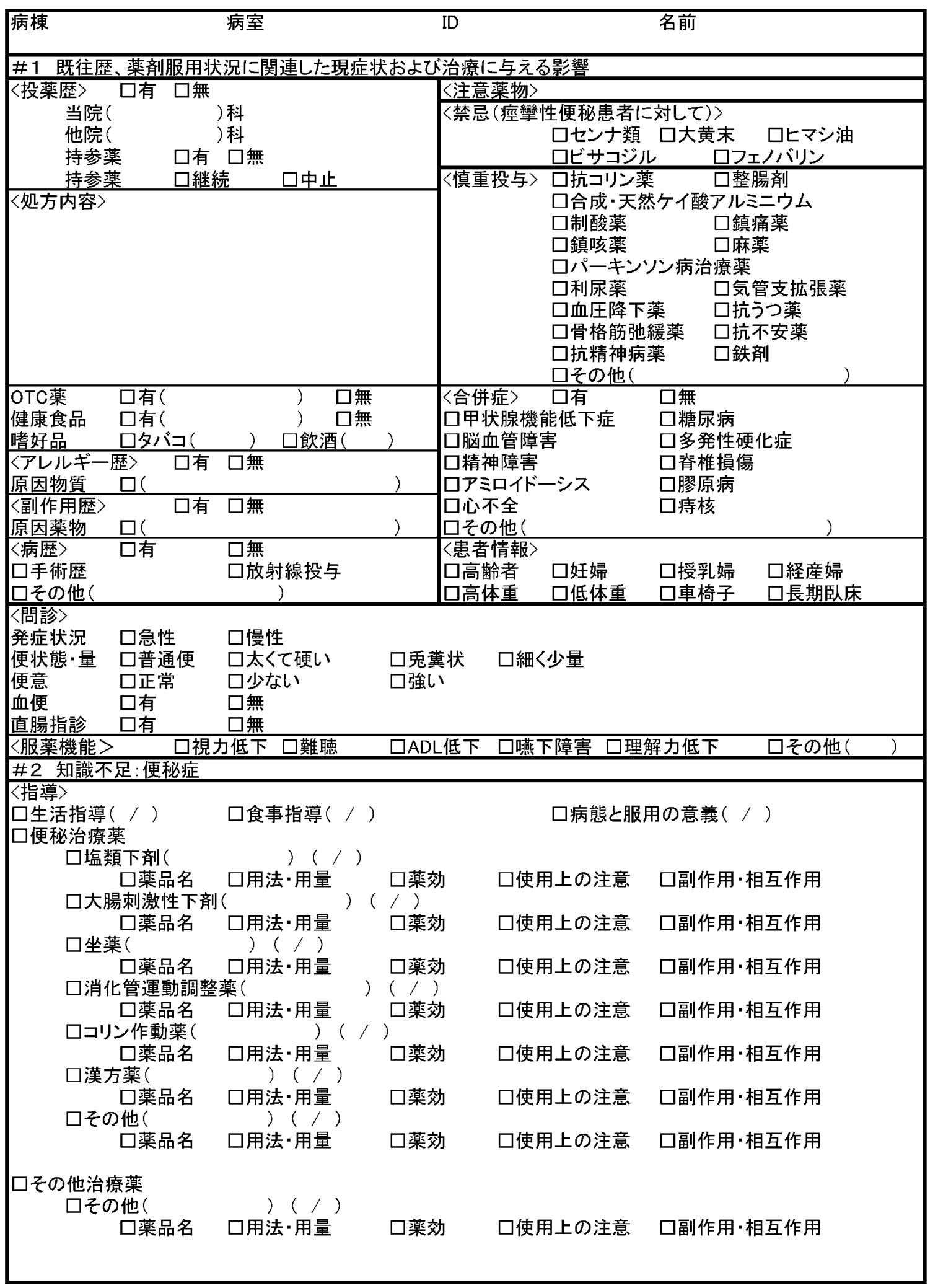


(図2の続き)

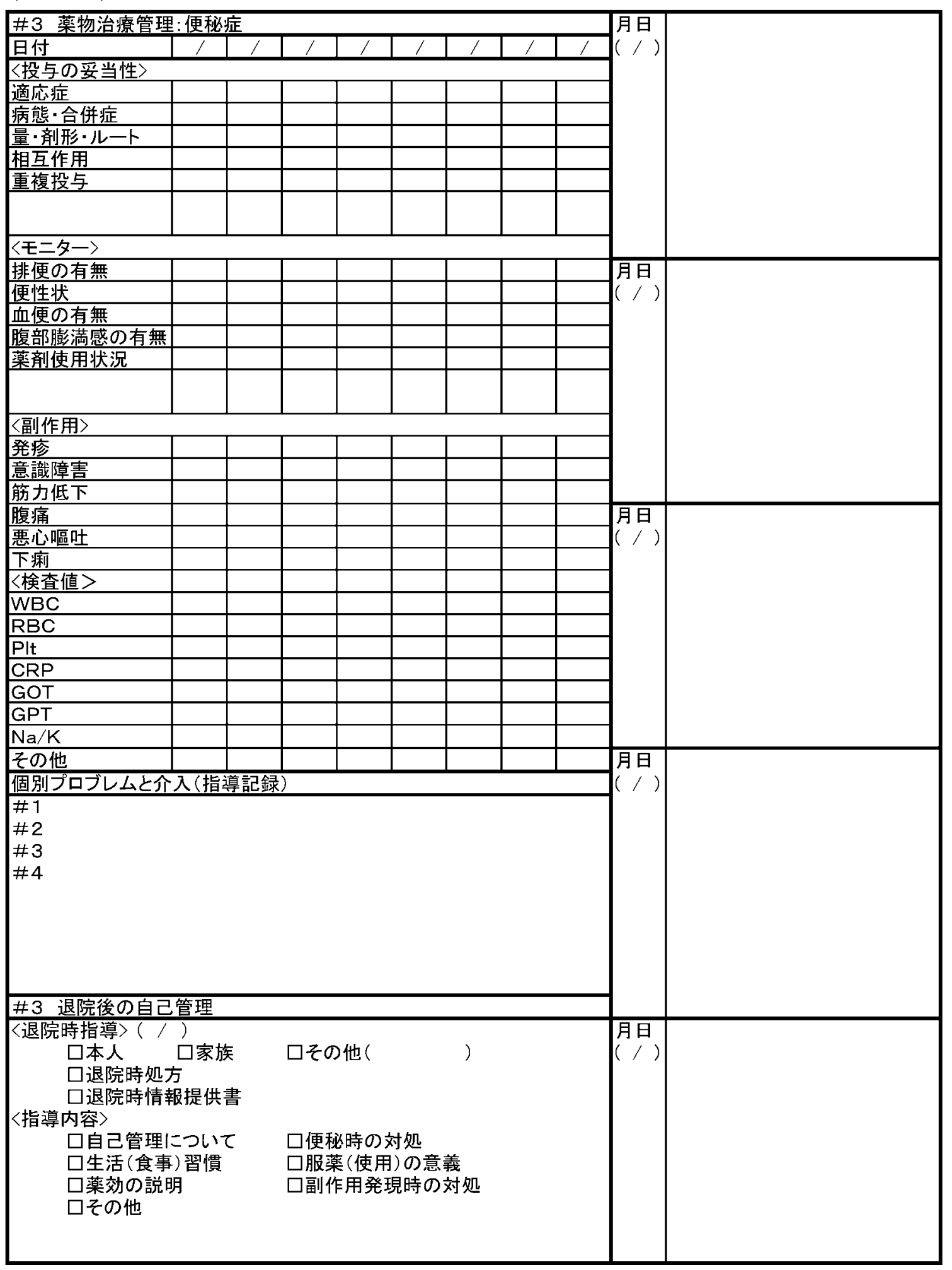




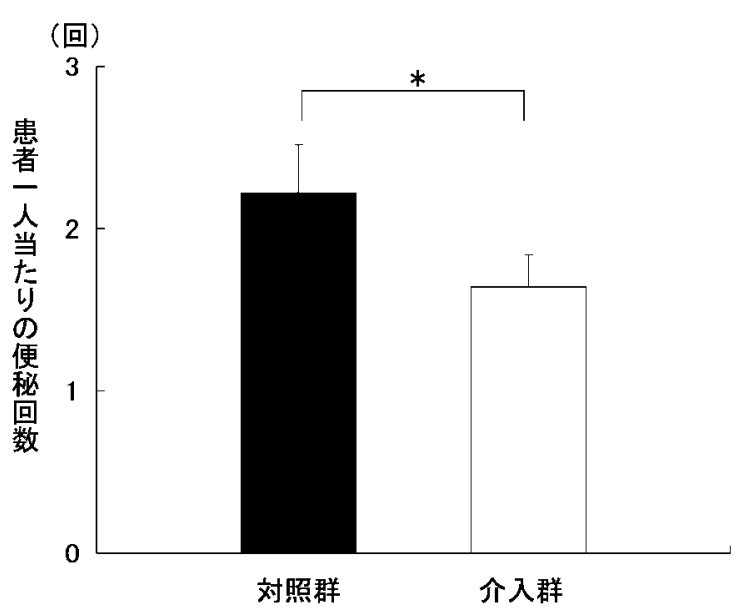

图 3. 介入による便秘回数の变化 ${ }^{*} \mathrm{p}<0.05$ (student t-test) 平均値士 標準誤差

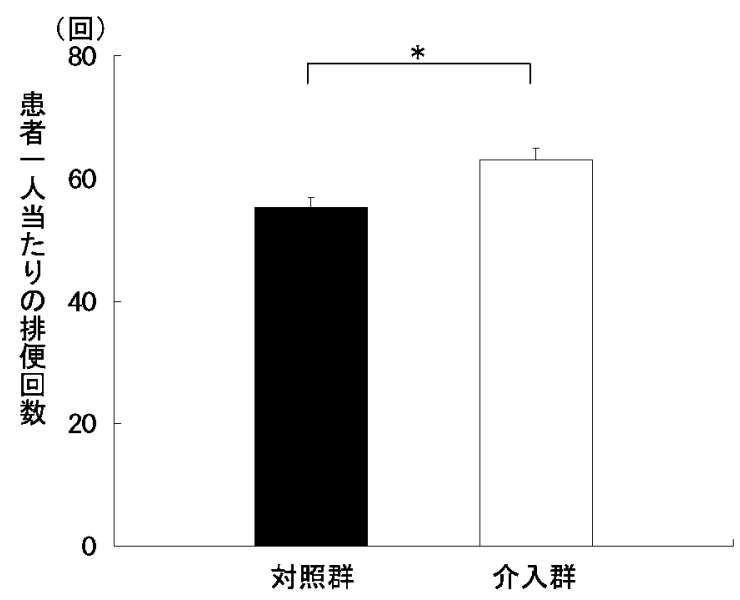

図 4.介入による排便回数の変化 ${ }^{*} \mathrm{p}<0.05$ (student $\mathrm{t}$-test) 平均值士 標準誤差

り，薬阁の増量のみに重点が置かれていたと考える．し かし，ヶアチームの介入により適切に薬効を評価するこ とで薬剤の減量が可能である例が多く含まれていた . 例 えば，抗コリン薬などの慎重投与薬阁の有無をチェック し，医師と協議の上，可能なかぎり中止・減量を実施す ることで, 緩下剤の増量を行うことなく「便秘症」の解 消が可能となった . したがって, ケアチームによる排便 コントロールへの共同介入は医療経済的にも有効であっ たと考える.さらに, 使用薬㶡量の変化では特に浣腸に よる強制排便が大きく減少したことから，患者のQOL 向上と看護師の排泄ヶアの業務量軽減にも寄与できたと 考える。

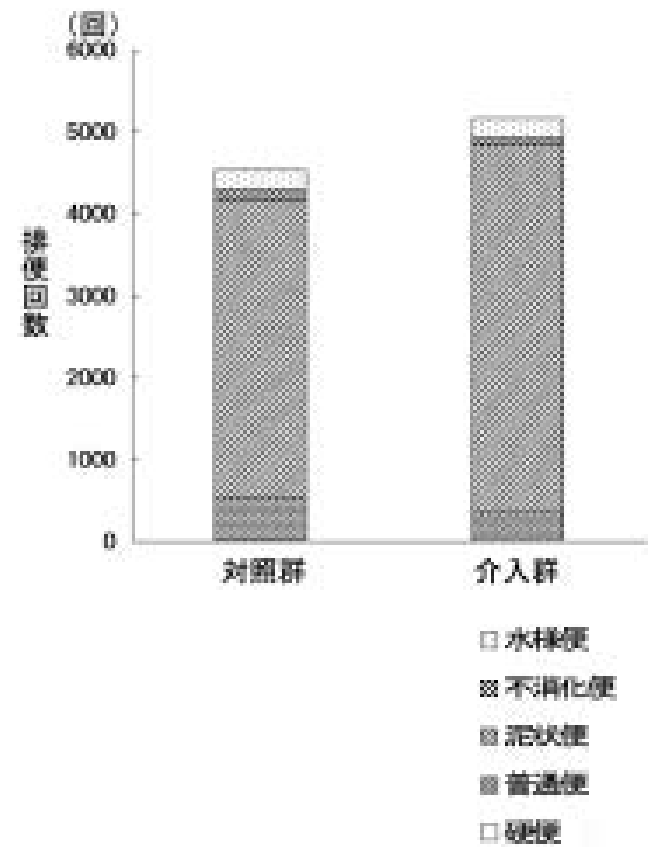

図 5. 介入による便性状の変化 各3力月間における排便回数の総計を 便性状毎に集計した.

表 3. 薬剂変更の内容と件数

\begin{tabular}{|l|r|r|}
\hline \multicolumn{1}{|c|}{ 変更内容 } & 対照群 & 介人群 \\
\hline \hline 增量 & 26 & 16 \\
\hline 減量 & 5 & 21 \\
\hline 追加・中止・投与時間 & 10 & 15 \\
\hline \hline 合計 & 41 & 52 \\
\hline
\end{tabular}

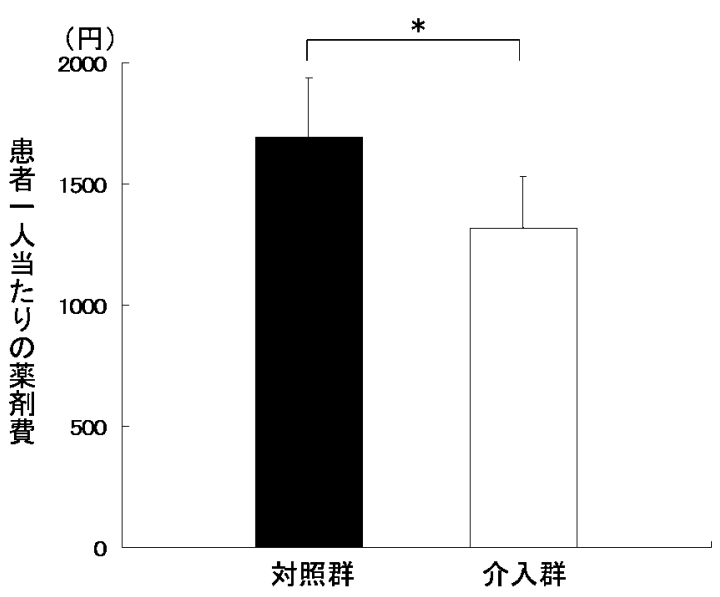

图 6. 介入による薬剂費の変化 ${ }^{*} \mathrm{p}<0.05$ (student t-test) 平均值士 標準誤差

現在，慢性期医療現場では診療報酬・介護報酬削減の 波が押し寄せ , スタッフの増員などが困難な状況にあ る、標準ヶア計画の一つである「便秘症」について, 薬 
表 4 . 使用薬剤量の変化

\begin{tabular}{|c|c|c|}
\hline 薬剬（単位） & 対照群 & 介入群 \\
\hline グリセリン浣腸 $60 \mathrm{~mL}$ (本) & 415 & 175 \\
\hline ビザコジル坐剤（個） & 574 & 458 \\
\hline ピコスルファートNa（滴） & 24,953 & 31,226 \\
\hline センノサイド (mg) & 142,555 & 130,855 \\
\hline 酸化マグネシウム（g） & 1,676 & 2,127 \\
\hline
\end{tabular}

剂師と看護師のケアチームが排便コントロールに共同介 入したことで，医療上有益な結果を得ることができた． より少人数で効率的な医療の実施か浗められている中， さらに高価な薬剂を使用するような疾患においては，こ れ以上の成果が期待される.

\section{引用文献}

1) 早川達“，POSによる標準ケア計画”，改訂 2版，じほ j, 東京, 2004, pp.3-7, pp.324-325.

2) 坂田睦, 重岡理恵, 玉川善洋, 安部宏子, 神村英利,
森川則文,精神科での POS (Problem Oriented System) を用いた薬斉管理指導業務 - 九州 POS薬剂研究会 における取り組み一，医療薬学，28，263-277 (2002).

3) 城田幹生, 早川不二子, 向井峰代, 大田正嗣, 森眞 由美，高齢者の多発性骨骾腫への標準ケア計画導入 と光の成果，医薬ジャーナル，40, 1732-1740 (2004).

4) 前田剛司, 鈴木大吾, 坂田洋, 早川達, 猪爪信夫, 肝硬変患者に対する標準ヶア計画の構築と臨床評 価，医療薬学，32, 110-117 (2006).

5）伊勢雄也, 和田和子, 金森麻土香, 千葉理実子, 向 後麻里, 吉尾隆, 伊東明彦, 村上純一郎, 平野公晟, 肝硬変患者におけるケアワークシート作成と薬学的 管理 - 東京都病院薬剂師会の取り組み一，医療薬 学, 31, 668-678 (2005).

6) 星加和徳，飯田三雄，便秘の診断ストラテジー-誰 に，いつ，どのような検査をすべきか, Medicina, 36, 1480-1484 (1999).

7) 草刈幸次, 安彦隆一, ベッドサイドの便秘の診か た, Medicina, 36, 1476-1478 (1999).

8) 木原彊, 便秘の治療, 臨床消化器内科 , 1, 1415-1422 (1986).

9) L.J. Carpenito“, 看護診断ハンドブック” , 2, 医学書 院, 東京, 1995, pp.371-374. 